\title{
GEOTOURISM DEVELOPMENT THROUGH THE PUBLIC FACILITIES IN GEOTRAIL BAKKARA, TOBA CALDERA GEOPARK
}

\author{
Nurlisa GINTING* \\ Universitas Sumatera, Department of Architecture, Faculty of Engineering, Monitoring Center for Sustainable Tourism \\ of Universitas Sumatera, Toba Lake \& Sustainable Tourism Working Group, Medan, Indonesia, e-mail: nurlisa@usu.ac.id \\ Vinky N. RAHMAN \\ Universitas Sumatera, Department of Architecture, Faculty of Engineering, Monitoring Center for Sustainable Tourism \\ of Universitas Sumatera, Toba Lake \& Sustainable Tourism Working Group, Medan, Indonesia, e-mail: n.vinky@usu.ac.id
}

Achmad D. NASUTION

Universitas Sumatera, Department of Architecture, Faculty of Engineering, Medan, Indonesia, e-mail: aan.nasution@gmail.com

Niswa A. DEWI

Universitas Sumatera, Monitoring Center for Sustainable Tourism of Universitas Sumatera, Medan, Indonesia, e-mail: niswadeaprlyn@gmail.com

Citation: Ginting, N., Rahman, V.N., Nasution, A.D., \& Dewi, N.A. (2021). GEOTOURISM DEVELOPMENT THROUGH THE PUBLIC FACILITIES IN GEOTRAIL BAKKARA, TOBA CALDERA GEOPARK. GeoJournal of Tourism and Geosites, 37(3), 914-920. https://doi.org/10.30892/gtg.37324-726

\begin{abstract}
Bakkara is a village with tourism potential in Geoarea Sibandang, Toba Caldera Geopark, one of UNESCO Global Geopark. This research was conducted to examine and review the geotourism development in Bakkara tourist destinations. Furthermore, the output of this research is to preserve the value of geotourism such as conservation, education, economy, and promotion, especially in public facilities. The method used in this study is a qualitative method through observation and focus group discussion. The results show that public facilities in the development of geotourism have been implemented but have not significantly affected tourism, and require some improvements.
\end{abstract}

Key words: geotourism, public facility, Bakkara, Toba Caldera Geopark

\section{INTRODUCTION}

One of the fastest-growing industries is tourism, improving a country's economy (Farid, 2015). Tourism development is essential, especially for Indonesia, which has many tourist attractions. Therefore, the development of tourist areas is crucial to improve the standard of living in the tourism area. Currently, the concept of sustainable tourism is the most widely used because it will create sustainability of a tourist destination in the future. One part of the concept of sustainable tourism is Geotourism. Geotourism can fulfill the tourists' desires and provide benefits to the environment and society as well as a trigger for local economic development in the area (Pralong, 2006).

Geopark and geotourism are the sustainable development models that help enhance the preservation of geoheritage and the environment (Gray, 2019) because the geological knowledge and geotourism are inclusive up to $30 \%$ as an important part of the geopark compositions (Singtuen et al., 2019). In terms of the geotourism concept, geotrail is one way to improve tourism potency and increase visitors to the geosite (Norrish et al., 2014). However, the main motivation of most geotourism visitors is tourists who want to have fun (Grobbelaar et al., 2019) and not geology. Therefore, geological park management requires geotourism development (Paungya et al., 2020). Geotourism development is one method to introduce tourism (Zouros et al., 2010). UNESCO introduced Geopark by forming an organization as UGG (UNESCO Global Geopark) which has the following criteria; the area is sufficient to accommodate geopark activities, the formation of management and involvement of local communities, local economic development, education for the public, conservation, and protection, and the Geopark must join a global geopark network and regional networks (UNESCO,2006). Today, UNESCO wants to achieve a geopark that combines conservation and sustainable development that can be economically beneficial to a particular area and educate local communities to understand their geological conditions and geographic implications. This understanding will develop local people's respect for their environment and maintain socio-cultural assets (Lin and $\mathrm{Su}$, 2019). Geopark aims to manage, protect, and promote landscapes that are considered to have extraordinary potential. Through geoheritage conservation, educate tourism through geotourism activities, and provide information to geopark-related residents, it is also hoped to achieve sustainable economic development in the area (Stoffelen et al., 2019). In July 2020, the Toba Caldera, better known as Lake Toba was designate at the 209th Session of the UNESCO Executive Boards in Paris, France, as a UNESCO Global

\footnotetext{
${ }^{*}$ Corresponding author
} 
Geopark. Toba Caldera Geopark has a large area consisting of several districts. Bakkara is one of the tourist destinations of Humbang Hasundutan Regency, which has the wondrous natural phenomena of Toba Caldera Geopark. Bakkara has magnificent potency for development in the tourism sector. In geotourism, public facility planning, which is one aspect of regional planning, is essential to enhance the convenience of tourists and residents. In the development of tourism in the geopark areas, interpretive facilities, and services are needed to enable tourists to understand the geology. This is seen as one of the contributions to support the development of the geopark areas (Álvarez, 2020). A public facility is an element that supports the center of public activity required for regional planning (Shirvani, 1985). Therefore, appropriate public facility arrangement is necessary to intensify the development of geotourism in Bakkara.

\section{MATERIALS AND METHODS}

There is eight elements of regional planning in Urban Design Theory, namely: (1) Land-use, (2) form of building and massing, (3) Circulation and parking, (4) Open space, (5) Pedestrian walkways, (6) Public facility, (7) Signage, and (8) Preservation (Shirvani, 1985). These elements require thorough planning to create an attractive and pleasant area. A public facility is one of the environmental design aspects that physically and non-physically maintain the inheritance of places and the sense of a place. Public facilities include all activities that strengthen the city's public spaces, such as recreation areas, public libraries, markets, and restrooms. This element is essential by providing visual stimulation and beneficial for tourists or locals. Public facilities in the Geopark, such as recreations, arts, and aesthetics, which tourists will feel, have a relationship with the public facility in an area and provide identity in tourist attractions (Ginting and Sasmita, 2018). Geotourism is the concept of developing tourism, which prioritizes natural resources and explores the geodiversity of areas that are a tourist attraction (Dowling, 2011).

Geotourism enhances the community's awareness of the fascinating things in the area that attracts many tourists to obtain sustainable tourism. Geotourism relies on the unique geology, stunning nature, and local's products as it progresses. Therefore, the concept of geopark-based arrangement does not require many capitals (Bujdosó et al., 2015). Geotourism aims to take community initiatives about the Geopark through infrastructure, society, and local economic growth. Also, geotourism focuses on world heritage through interpretation and education (Dowling and Newsome, 2010). In this research, the indicators of education aspect for the development of geotourism through the public facility in the research location are comprehension and development of geosite; appreciation of world heritage and cultural values through interpretation and education; and educational activities. One of the measures to develop geotourism is through commercial products by locals aim to increase the tourists. Improving local products and appropriate marketing strategies can comply with the needs of tourists (Pralong, 2006). One of the methods to introduce tourism is by identifying geotourism as a marketing strategy to escalate the geosite (Gerner et al., 2009). Associating biodiversity conservation, geotourism, and community development help reduce resource degradation and elevate sustainable local development (Dowling and Newsome, 2006; Chen et al., 2015). In this research, the indicators of economic aspects of geotourism development through the public facility are marketing and local product improvement.

The concept of Geotourism is often implemented lately to preserve the earth's heritage, the growth of public awareness towards the earth's geological issue, and the number escalation of geoparks (Ren et al., 2013). Meanwhile, geotourism also concerns the geology and landscape of tourism and promotes tourism by conserving and preserving geodiversity through interpretation and education (Dowling and Newsome, 2010). In this study, the factors that affecting the conservation aspect as the development of geotourism through the public facility are geosite conservation and sustainability of geosite. According

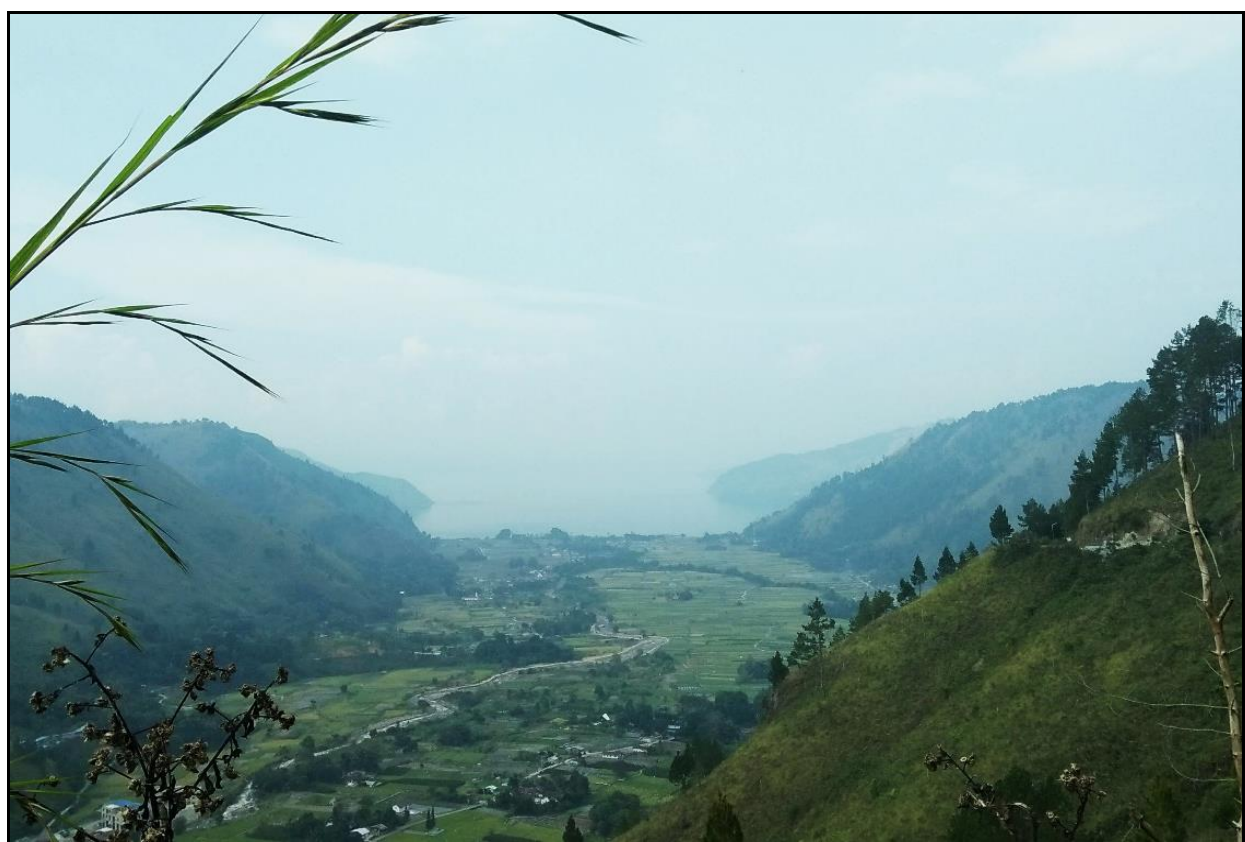

Figure 1. Geotrail Bakkara (Source: Author, 2019) to Hose (2006), indicators of the successful implementation of the concept of geotourism are physical identification and promotion, user comprehension, and efforts to elevate and disseminate the capable and communicative interpretation media (Hose, 2006). Therefore, in this study, the factors that affect the promotion aspect as well as the development of geotourism through the public facility are the image of the destination and the development of tourism products. Thus, geotourism has four aspects, namely Education, Economics, Conservation, and Promotion, which create an increase in destination tourism (Pralong, 2005). The research location is 
Bakkara village in Baktiraja Sub-district, Humbang Hasundutan Regency, North Sumatera Province, Indonesia (Figure 1). Bakkara is located in Geoarea Sibandang, one of the larval domes in Toba Caldera Geopark (De Silva et al., 2015).

Bakkara has a lot of diversity in the Toba Caldera Geopark area, which is potential and worthy of being developed. Bakkara location is about $20 \mathrm{~km}$ from Humbang Hasundutan Regency, Dolok Sanggul, and $211 \mathrm{~km}$ from Medan City. This research focuses on seven research points as frequently visited tourist objects in Bakkara: Bakkara Scenery, Aek Sitio-tio, Sisingamangaraja Palace, Aek Sipangolu, Hariara Tungkot, Janji Waterfall, and Tombak Sulu-sulu (Figure 2).

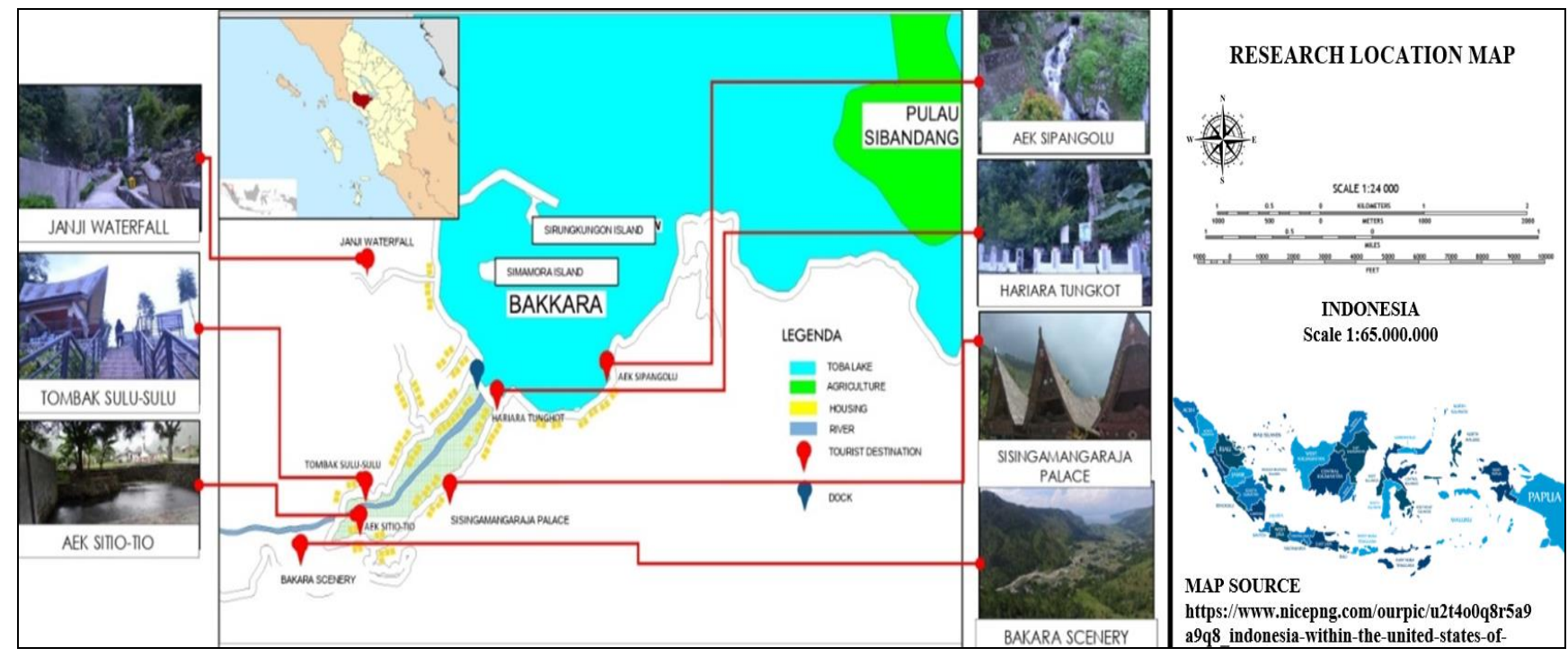

Figure 2. Research Area (Source: Author, 2019)

This research aims to find the concept of tourism planning on the arrangement of public facilities based on current observations to increase the geotourism development in the research location (Figure 3). This research uses a qualitative method by describing current observations in the Bakkara tourist area. Qualitative research methods not only have a concern for the data found while also examining the socio-culture at the research location, thus producing contextual findings (Groat and Wang, 2013). Qualitative research method data are generally more in figures and sentences than numbers (Fraenkel et al., 1993). This research implements the theory of geotourism development presented by the arrangement of public facilities as a component of the Urban Design theory by Shirvani Hamid (Shirvani, 1985).

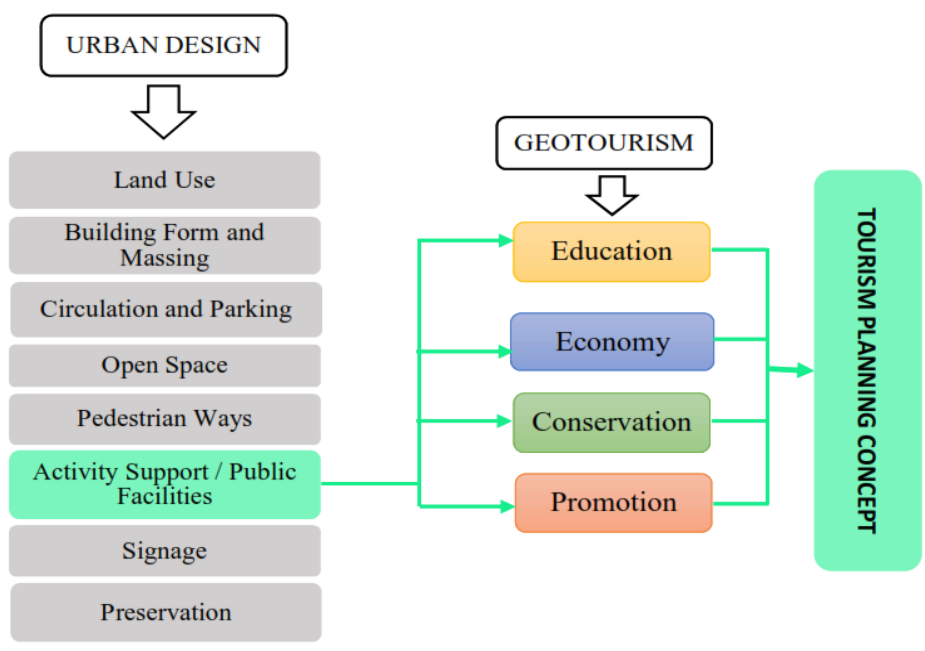

Figure 3. Analysis Chart (Source: Author, 2019)

\section{RESULTS AND DISCUSSION}

\section{Education Aspect}

Geotourism concerns world heritage and cultural values through interpretation and education (Dowling and Newsome, 2006). Geotourism must offer knowledge and educate tourists about the geodiversity of the tourist attractions and provide tourist satisfaction by requiring infrastructure and supporting tourism (Henriques et al., 2012).

The tourist Information Center is one of the tourist amenities in the tourism area by exploring the attractions. Unfortunately, most of the tourism destinations in Bakkara have not provided the Tourist Information Center. Instead, the Tourist Information Center provides information and guidance for tourists on destinations, accommodations, attractions, entertainment centers, maps, and everything related to tourism (Suwintari, 2012). Besides, some tourist destinations in Bakkara have provided signage, such as in Sisingamangaraja Palace and Janji Waterfall (Figure 4). However, most signs do not provide much information related to geotourism or Geopark, and its maintenance is relatively low (Figure 5).

As for the education aspect in terms of geotourism, the Tourist Information Center and signage help educate the public about the geotourism or Geopark. Geopark education management aims to initiate and raise Geopark's public education and all social elements to enhance economic and infrastructure development. Amenities by the host community in the geosite area will support various tourism activities that facilitate and educate tourists (Ginting and Sasmita, 2018). Therefore, to promote the geotourism in Bakkara, tourist attractions should provide the appropriate Tourist Information Center and signages to initiate and educate people about geotourism or geosite. 


\section{Economics Aspect}

Service development will encourage the principle of geotourism to involve locals in developing innovative strategies (Sunaryo, 2013). The establishment of Geopark contributes to supporting local food, local products, and local accommodations (Singtuen et al., 2019). Toba Caldera Geopark provides many benefits, one of which is for sustainable economic growth and development. The arrangement of appropriate tourism facilities will increase the number of visitors and tourists as they impact the economic growth of the locals in the tourism sector.
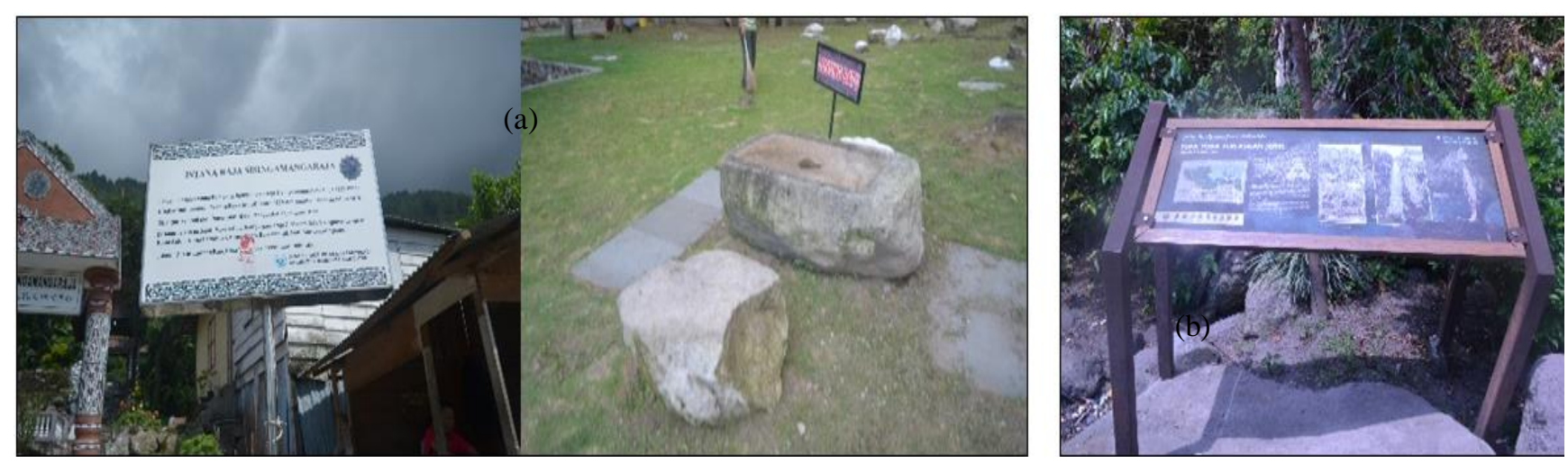

Figure 4. Information Signage of Tourist Destination in Bakkara: (a) Sisingamangaraja Palace (b) Janji Waterfall (Source: Author, 2019)
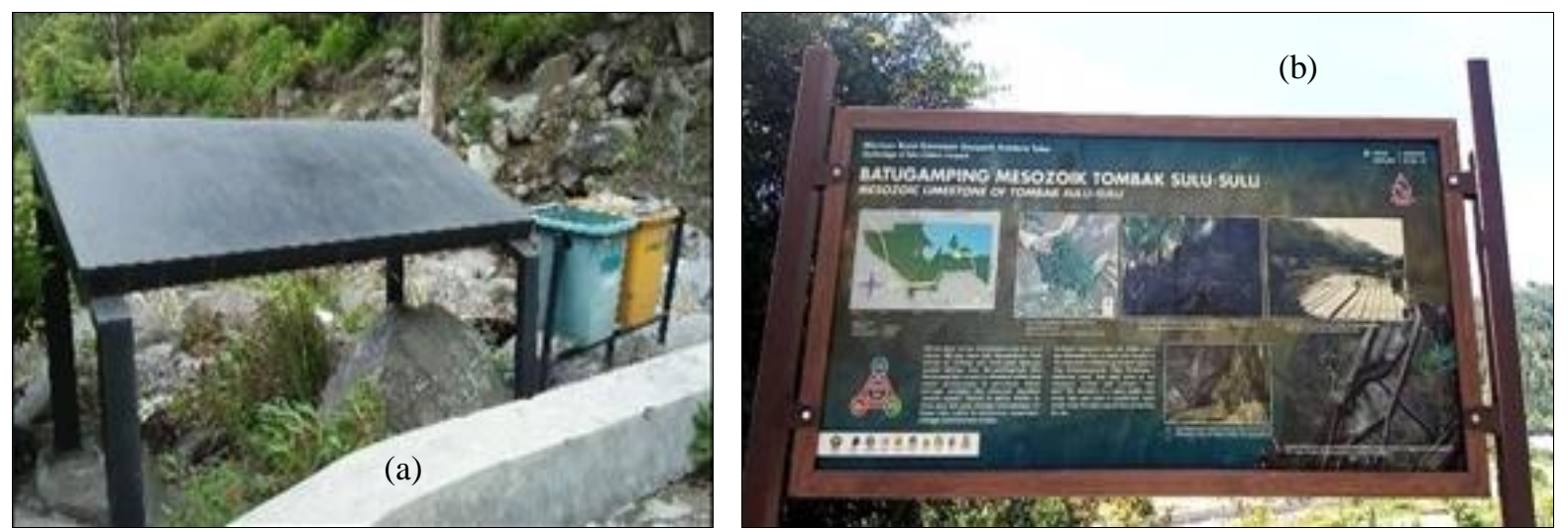

Figure 5. Condition of Tourism Destination Signages in Bakkara: (a) Janji Waterfall (b) Tombak Sulu-Sulu (Source: Author, 2019)

Bakkara is well known for its quality and special agricultural products, such as onions, coffee beans, and rice, which will increase the economic value of Bakkara if adequately preserved (Figure 6). Unfortunately, some tourism destinations in Bakkara do not provide a souvenir shop as well as promoting and selling its natural wealth.

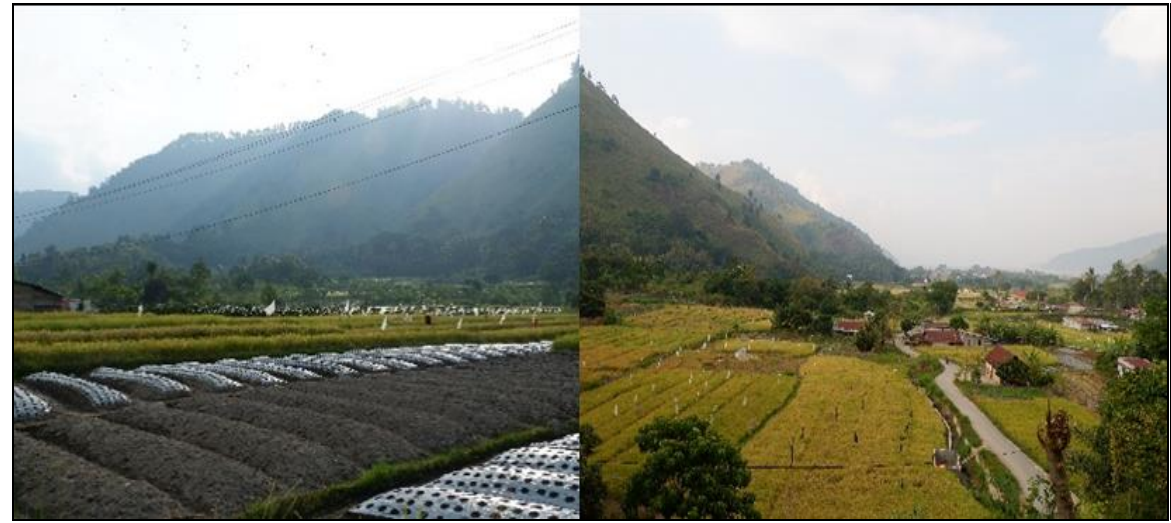

Figure 6. Agriculture in Bakkara

(Source: Author, 2019)

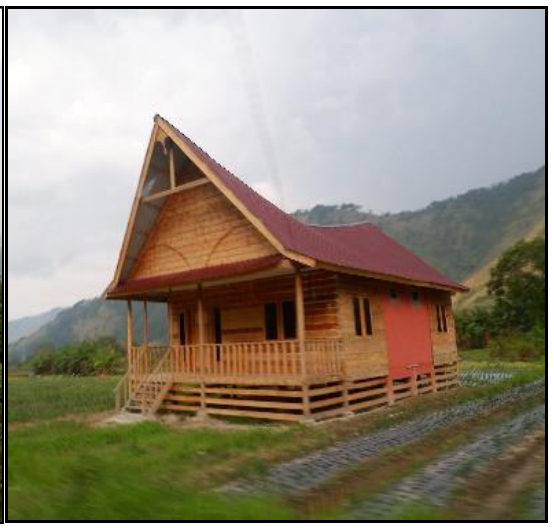

Figure 7. Local House in Bakkara which Potentially can be Homestay

The tourists should spend everything related to creativity in improving the local economy (Swarna et al., 2013). Lodging and eatery facilities are also public facilities in tourist areas that are useful in improving the host economy. However, some tourist destinations in Bakkara have not provided the eatery as the rest area for tourists. The eatery is beneficial for tourists as well as employing locals to improve the local economy. Besides, lodging facilities are still rarely found in the tourist destinations, while nearby lodging facilities are $1 \mathrm{~km}$ away downtown. 
According to Sunaryo (2013), service development will encourage the principle of geotourism to involve locals in developing innovative strategies (Sunaryo, 2013). The souvenir shop is an important support facility and has the potential to elevate the economy of the locals. Therefore, one of the efforts to develop geotourism from the economic aspect is by providing several souvenir shops in each tourist attraction. The souvenir shop must also be properly maintained by the locals to preserve sustainability. Moreover, some local houses have the potency to be developed as Homestays (see Figure 7). The improvement of public facilities will increase tourist amenities. Otherwise, the economic growth will affect the locals around the tourist attractions in Bakkara (Ginting et al., 2017).

\section{Conservation Aspects}

Tourism is to improve the economy and the locals' prosperity and is necessary for the sustainability of custom, tradition, and culture (Lutfianti, 2017). Historical heritage is the attractiveness of a tourist destination (Ginting and Wahid, 2016). As a tourist destination, Bakkara has a great geodiversity, biodiversity, and cultural diversity. Some of the tourist attractions that have cultural diversity are Hariara Tungkot, Tombak Sulu-sulu, and Sisingamangaraja Palace, which build the area's character. Meanwhile, several natural tourist destinations in Bakkara are Aek Sipangolu, Janji Waterfall, Tombak Sulu-sulu, Bakkara Scenery, and Aek Sitio-tio, which contains a diversity of Toba Caldera Geopark.

Bakkara is famous for its culture of Toba Batak because the ethnicity of the population is Toba Batak. The cultural diversity in Bakkara needs proper conservation as the historical building is a historical heritage from ancient times, which is important and has a unique sense of science and educational knowledge. Therefore, by presidential regulation number 9 of 2019, the preservation of Geological Heritage, Biodiversity, and cultural diversity between the Central Government, Government Regions, and Stakeholders through 3 (three) pillars covering conservation, education, and economic development efforts for the society in a sustainable manner. One of the conservation efforts carried out in the Bakara area was the rebuilding of the Sisingamangaraja Palace, which was burned in 1825 and rebuilt by the government in 1978.

Several public facilities in Bakkara have been adequately conserved (see Figure 8), but some of the architectural designs are not harmonious with the Toba Batak architectural style's identity. In addition, vandalism has been found in some tourist destinations, which means that public facilities in tourist areas are poorly preserved (Figure 9).

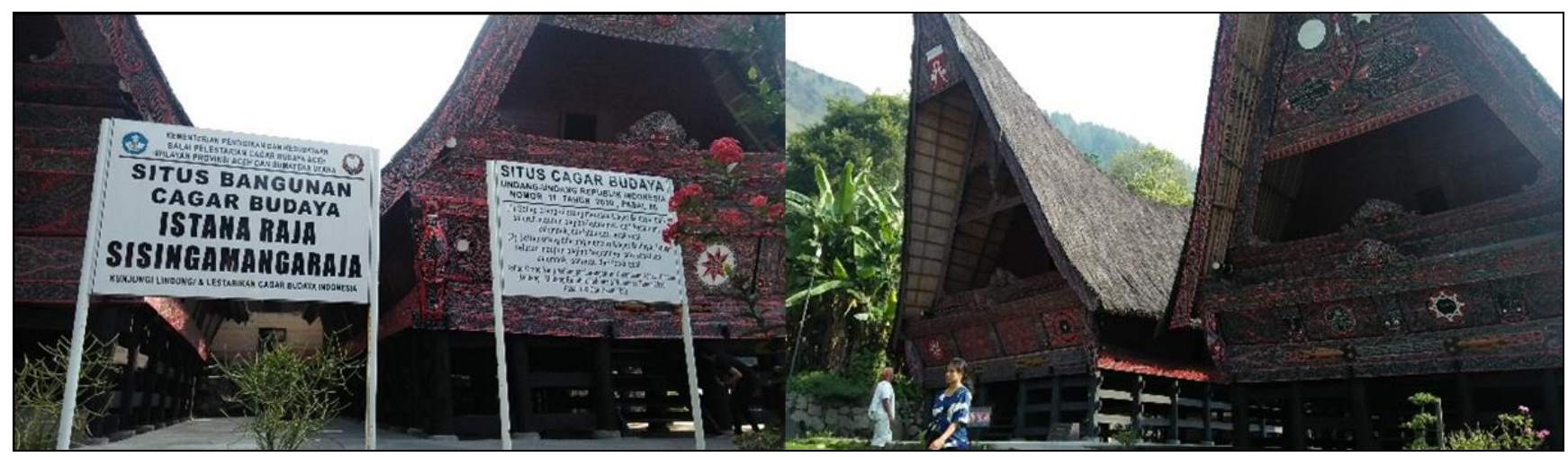

Figure 8. Conservation Aspect Concerning Public Facilities In Istana Sisingamangaraja, Bakkara (Source: Author, 2019)

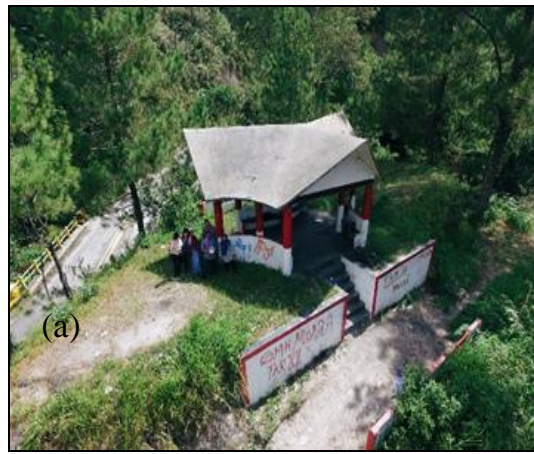

Figure 9. Vandalism in Bakkara's Tourist Destinations (a) Pavilion Bakkara (b) Aek Sipangolu (Source: Author, 2019)

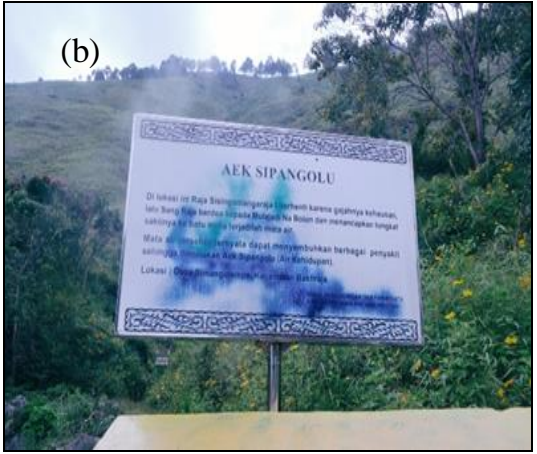

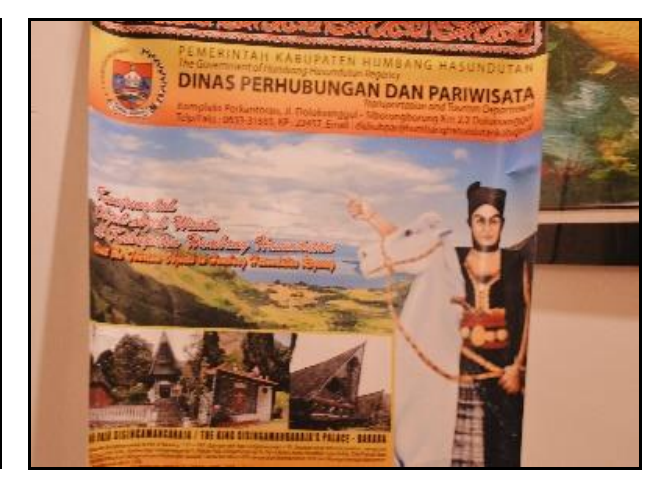

Figure 10. Banner of Bakkara Tourism (Source: Author, 2019)

Kotler et al. (2006) said that distinctive geotourism effects specific to this area are significant for future geotourism and geopark sustainability capabilities and, while still requiring appropriate management to sustain the destination products (Kotler et al., 2006). Some public facilities in Bakkara have been adequately conserved, but some of the architectural designs are not harmonious with the Toba Batak architecture style identity. Meanwhile, there is a need to restructure public facilities in tourist attractions areas (Zainol et al., 2011). Facilities and services by locals in the tourist area will contribute to tourism activities (Ginting and Sasmita, 2018). Stakeholders must maintain the facilities properly as keeping sustainability and tourist amenities. Unfortunately, vandalism at the stop point in the Bakkara Scenery, which is one of the tourist attractions in 
Bakkara, caused the aesthetics' reduction as a tourist attraction. Thus, a stopping point requires proper maintenance from stakeholders, tourists, and locals, while the cleanliness of the attraction will affect tourists' escalation (Ginting et al., 2017).

\section{Promotion Aspect}

The success of the implementation of the geotourism is indicated by its physical promotion activities (Hose, 2006). By promoting tourism, introducing geotourism to the public will be easier as the initial step to escalate tourists and visitors. Tourism promotion activities are necessary for facilitating the public about tourism destinations.

However, local wisdom is one of the methods to promote tourism creatively, and tourism stakeholders should be aware of this (Singsomboon, 2014). According to UNESCO, Toba Caldera Geopark has been designated as a UNESCO Global Geopark in July 2020, which provides many benefits and impacts to the tourism promotion in Toba Caldera Geopark as well as for Bakkara as part of Toba Caldera Geopark. Unfortunately, the condition of public facilities for promotion purposes in Bakkara is quite defective. Some tourist attractions have not presented feature elements of street furniture for advertising purposes, attracting tourists. Meanwhile, the local government has conducted promotion activities by presenting some banners about Bakkara tourism at several hotels in Doloksanggul Town, Humbang Hasundutan Regency (Figure 10). Furthermore, several articles on several travel websites show online promotional activities, which have a positive impact on tourism in Bakkara. This study emphasizes that promotional activities in Bakkara are more encouraged online than physically. Communication to the public significantly influences the projects' hits, and the internet provides a precise instrument for promotion efforts (Yolal, 2012).

However, physical promotion is as necessary as online promotion, which is indicated by the support of activities or the public facilities at the tourist destination. Inadequacy promotion will influence the image of tourist destinations. The approach to public facilities such as hotels in the Geopark area will influence tourism. The significance of explanation in geotourism programs should be promoted to escalate tourism awareness and nature esteem (Hakim and Soemarno, 2017). Therefore, promotional activities from stakeholders or locals in Bakkara must be conducted more intensively, actively, and enterprising as improving the geotourism in Bakkara.

\section{CONCLUSION}

In the research location, the public facilities in the aspects of economics, education, conservation, and promotion as geotourism development have been implemented but have not had a significant impact on tourism. Public facilities such as stop points, restrooms, streetlights, eatery, lodging, and signage have applied and implemented but have not reached the appropriate level of maintenance. The inadequacy of understanding and contribution of stakeholders and locals has led to a slight improvement in the development of Bakkara geotourism.

From the economic aspect, locals and local government should play an active role in providing several eateries and homestays as Bakkara has good potential to escalate the development of geotourism. In addition, each tourist attraction is required to establish the Tourist Information Center and educational signboard related to geotourism and Toba Caldera Geopark to realize the development of geotourism in education. Besides, educational activities related to the geotourism are also essential to actualize as an effort to increase the awareness of the geotourism. It is necessary to have signage at each tourist locations to describe the object and its history.

From the conservation aspect, public tourism facilities are equally important with the tourist attraction, and must properly be maintained. The tourist attraction and its public facilities must prioritize hygiene, sanitation, preservation, and conserve the area to promote the development of geotourism in Bakkara. Proper management of public facilities in tourist areas will implicitly promote the tourist attraction. However, stakeholders, locals, and the government should be actively promote effectively escalate the tourist attraction and the geotourism in Bakkara impressively. This study recommends future research on the development of geotourism in Bakkara, Toba Caldera Geopark.

\section{Acknowledgment}

The researchers wish to acknowledge the DRPM Ministry of Research and Technology and the Higher Education Republic of Indonesia under the research grant of number 252/UN5.2.3.1/PPM/KP-DRPM/2018 the Year 2018.

\section{REFERENCES}

Álvarez, R.F. (2020). Geoparks and education: UNESCO global geopark Villuercas-Ibores-Jara as a case study in Spain. Geosciences (Switzerland), 10(1). https://doi.org/10.3390/geosciences 10010027

Bujdosó, Z., Dávid, L., Wéber, Z., \& Tenk, A. (2015). Utilization of Geoheritage in Tourism Development. Procedia - Social and Behavioral Sciences, 188, 316-324. https://doi.org/10.1016/j.sbspro.2015.03.400

Chen, A., Lu, Y., \& Ng, Y.C. (2015). The principles of geotourism. Berlin: Springer Berlin Heidelberg. https://doi.org/10.1007/978-3-662-46697-1

De Silva, S.L., Mucek, A.E., Gregg, P.M., \& Pratomo, I. (2015). Resurgent Toba-Field, chronologic, and model constraints on time scales and mechanisms of resurgence at large calderas. Frontiers in Earth Science, 3, 25. https://doi.org/10.3389/feart.2015.00025

Dowling, R.K. (2011). Geotourism's global growth. Geoheritage, 3(1), 1-13. https://doi.org/10.1007/s12371-010-0024-7

Dowling, R.K., \& Newsome, D. (2006). Geotourism's issues and challenges. Geotourism, 242-254. 10.1016/B978-0-7506-62154.50021-X. https://doi.org/10.4324/9780080455334-25

Dowling, R.K., \& Newsome, D. (Eds.). (2010). Global geotourism perspectives. Goodfellow Publishers Limited.10.1007/s12371-0100024-7. https://doi.org/10.1016/j.tourman.2010.11.006

Farid, S.M. (2015). Tourism management in world heritage sites and its impact on economic development in Mali and Ethiopia. ProcediaSocial and Behavioral Sciences, 211, 595-604.10.1016/J.SBSPRO.2015.11.078 https://doi.org/10.1016/j.sbspro.2015.11.078 
Fraenkel, J.R., Wallen, N.E., \& Hyun, H.H. (1993). How to design and evaluate research in education. 7, New York: McGraw-Hill. http://highered.mheducation.com/sites/0078110394

Gerner, D., Rybár, P., Engel, J., \& Domaracká, L. (2009). Geotourizm marketing in Lake Constance'region. Acta Montanistica Slovaca, 14(2), 197. https://core.ac.uk

Ginting, N., Rahman, N.V., \& Sembiring, G. (2017). Tourism development based on Geopark in Bakkara Caldera Toba, Indonesia. In IOP Conference Series: Materials Science and Engineering, 180. https://doi.org/10.1088/1757-899X/180/1/012086

Ginting, N., \& Sasmita, A. (2018). Developing tourism facilities based on geotourism in Silalahi Village, Geopark Toba Caldera. In IOP Conference Series: Earth and Environmental Science, 126. https://doi.org/10.1088/1755-1315/126/1/012163

Ginting, N., \& Wahid, J. (2016). Recalling the Past: Maintaining continuity in urban heritage tourism. Journal of ASIAN Behavioural Studies, 1(1), 81-89. https://doi.org/10.21834/jabs.v1i1.174

Gray, M. (2019). Geodiversity, geoheritage and geoconservation for society. International Journal of Geoheritage and Parks, 7(4), 226236. https://doi.org/10.1016/j.ijgeop.2019.11.001

Groat, L.N., \& Wang, D. (2013). Architectural research methods. John Wiley \& Sons.

Grobbelaar, L., Bouwer, S., \& Hermann, U.P. (2019). An Exploratory Investigation of Visitor Motivations to the Barberton-Makhonjwa Geotrail, South Africa. GeoJournal of Tourism and Geosites, 25 (2). https://doi.org/10.30892/gtg.25101-359

Hakim, L., \& Soemarno, M. (2017). Biodiversity conservation, community development and geotourism development in bromotengger-semeru-arjuno biosphere reserve. Geojournal of Tourism and Geosites, 20(2), 220-230. http://gtg.webhost.uoradea. ro/PDF/GTG-2-2017/228_Hakim.pdf

Henriques, M.H., Tomaz, C., \& Sá, A.A. (2012). The Arouca Geopark (Portugal) as an educational resource: a case study. Episodes, 35(4), 481-488. https://doi.org/10.18814/epiiugs/2012/v35i4/004

Hose, T.A. (2006). Geotourism and interpretation. Geotourism, 22. https://doi.org/10.1007/s12371-011-0052-y

Kotler, P., Bowen, T.J., \& Makens, C.J. (2006). Marketing for Hospitality and Tourism, Pearson Education. Inc., Upper Saddle River, New Jersey.

Lin, J.C., \& Su, S.J. (2019). A New Way of Understanding Geoparks for Society. 55-67. https://doi.org/10.1007/978-3-030-04895-2_2

Lutfianti, E. (2017). Geotrail planning of geotourism area Cimenyan Sub-District, Bandung Regency. ASEAN Journal on Hospitality and Tourism, 15(1), 12. 10.5614/ajht.2017.15.1.5. https://doi.org/10.5614/ajht.2017.15.1.5

Norrish, L., Sanders, D., \& Dowling, R. (2014). Geotourism product development and stakeholder perceptions: a case study of a

proposed geotrail in Perth, Western Australia. Journal of Ecotourism, 13(1), 52-63. https://doi.org/10.1080/14724049.2014.938654

Paungya, N., Singtuen, V., \& Won-In, K. (2020). The Preliminary Geotourism Study in Phetcahbun Province, Thailand. GeoJournal of Tourism and Geosites, 31(3), 1057-1067. https://doi.org/10.30892/gtg.31318-541.

Pralong, J.P. (2005). A Method for Assessing Tourist Potential and Use of Geomorphological Sites. Géomorphologie: Relief, Processus, Environnement, 11(3), 189-196. https://doi.org/10.4000/geomorphologie.350

Pralong, J.P. (2006). Geotourism: A New Form of Tourism Utilising Natural Landscapes and Based on Imagination and Emotion. Tourism Review, 61(3), 20-25. https://doi.org/10.1108/eb058476

Ren, F., Simonson, L., \& Pan, Z. (2013). Interpretation of geoheritage for geotourism-a comparison of Chinese geoparks and national parks in the United States. Czech Journal of Tourism, 2(2). https://doi.org/10.2478/cjot-2013-0006

Shirvani, H. (1985). The Urban Design Process Van Nostrand Reinhold. Co, New York.

Singsomboon, T. (2014). Tourism promotion and the use of local wisdom through creative tourism process. International journal of business tourism and applied sciences, 2(2), 32-37.

Singtuen, V., Gałka, E., Phajuy, B., \& Won-In, K. (2019). Evaluation and Geopark Perspective of the Geoheritage Resources in Chiang Mai Area, Northern Thailand. Geoheritage, 11(4), 1955-1972. https://doi.org/10.1007/s12371-019-00410-0

Stoffelen, A., Groote, P., Meijles, E., \& Weitkamp, G. (2019). Geoparks and territorial identity: A study of the spatial affinity of inhabitants with UNESCO Geopark De Hondsrug, The Netherlands. Applied Geography, 106, 1-10. https://doi.org/10.1016/j.apgeog.2019.03.004

Sunaryo, B. (2013). Kebijakan pembangunan destinasi pariwisata: konsep dan aplikasinya di Indonesia (No. 1). Penerbit Gava Media Kebijakan Pembangunan Destinasi Pariwisata: Konsep dan Aplikasinya di Indonesia, (In Indonesian). https://repository.ugm.ac.id/id/eprint/101212

Suwintari, I.G.A.E. (2012). Kepuasan Wisatawan terhadap Kualitas Pelayanan Tourist Information Counters di Jalan Padma Utara Legian, Kuta. Jurnal Ilmiah Hospitality Management, 2(2), (In Indonesian). https://doi.org/10.22334/jihm.v2i2.77

Swarna, K., Biswas, S.K., \& Harinarayana, T. (2013). Development of geotourism in Kutch Region, Gujarat, India: an innovative approach. Journal of Environmental Protection, 4(12), 1360-1372. https://doi.org/10.4236/jep.2013.412157

Yolal, M. (2012). Geotourism and geoparks: the case of Kizilcahamam-Çamlidere Geopark. GeoJournal of Tourism and Geosites, 10(2), 193-203. http://gtg.webhost.uoradea.ro/V20122_vol10.html

Zainol, N.Y., Yacob, I., Muhammad, M., Abd Manap, H., \& Said, I.M. (2011). Implementing Langkawi Geopark Through Land Use Planning. PLANNING MALAYSIA, 1(1). http://dx.doi.org/10.21837/pm.v1i1.90

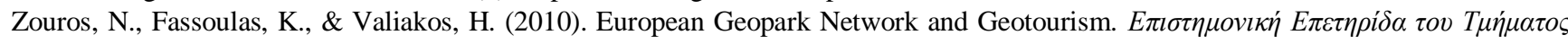

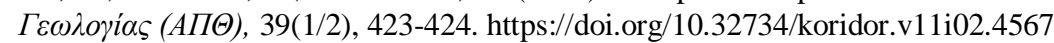

Article history: Received: 30.12.2020 Revised: 12.06.2021 Accepted: 31.08.2021 Available online: 21.09.2021 